\title{
Studi Antropometri Mahasiswa Indonesia Bersuku Batak Dan Jawa
}

\author{
Ismianti $^{1}$, Herianto ${ }^{2}$, dan Ardiyanto Ardiyanto ${ }^{2}$ \\ ${ }^{1)}$ Program Studi Teknik Industri, UPN "Veteran" Yogyakarta \\ ${ }^{2)}$ Departemen Teknik Mesin dan Industri, Universitas Gadjah Mada, Yogyakarta \\ e-mail korespondensi: ismianti@ upnyk.ac.id ${ }^{1)}$ \\ doi:https://doi.org/10.24843/JEI.2019.v05.i02.p01
}

Article Received: 23 Nopember 2019; Accepted: 30 Desember 2019; Published: 31 Desember 2019

\begin{abstract}
Abstrak
Perbedaan suku bangsa merupakan salah satu faktor yang berpengaruh terhadap variasi antropometri. Walaupun Indonesia terdiri dari berbagai suku bangsa, penelitian antropometri yang membahas hal tersebut masih sangat terbatas. Penelitian ini dilakukan untuk mengumpulkan data antropometri mahasiswa Indonesia, sekaligus membandingkan dimensi antropometri antara mahasiswa Indonesia bersuku Batak dan Jawa. Pengukuran 58 dimensi antropometri dilakukan pada 286 mahasiswa laki-laki dan 210 mahasiswa perempuan. Hasil pengukuran disajikan dalam statistik deskriptif dalam rerata, simpang baku, dan nilai persentil. Selain itu, perbandingan antropometri antar jenis kelamin dan suku dilakukan dengan uji t dan uji Mann-Whitney. Hasil perbandingan pada peserta perempuan dan laki-laki untuk masing-masing suku menunjukkan perbedaan yang signifikan hampir di seluruh dimensi, di mana peserta laki-laki cenderung memiliki dimensi yang lebih besar daripada perempuan $(\mathrm{p}<0.05)$. Perbandingan antropometri antar suku pada peserta laki-laki menunjukkan bahwa terdapat perbedaan signifikan pada 13 dimensi dengan kecenderungan laki-laki bersuku Jawa memiliki dimensi kaki yang lebih besar, sedangkan peserta laki-laki bersuku Batak memiliki dimensi lebar seperti lebar mulut dan lebar kaki yang lebih besar. Pada peserta perempuan, terdapat perbedaan yang signifikan pada 27 dimensi di mana terdapat kecenderungan peserta bersuku Batak memiliki dimensi posisi duduk menghadap belakang yang lebih besar, sedangkan peserta bersuku Jawa cenderung memiliki dimensi tangan yang lebih besar.
\end{abstract}

Kata kunci: dimensi, antropometri, perbandingan, suku Batak, suku Jawa

\section{Anthropometric Study of Indonesian Bataknese and Javanese College Students}

\begin{abstract}
Anthropometric variations can be attributed to ethnic differences. Although Indonesia consists of many ethnic groups, anthropometric studies discussed this issue were still very limited. This research was conducted to collect anthropometric data of Indonesian Bataknese and Javanese college students. Comparisons of anthropometric dimensions between the two ethnic groups were also performed in this study. Anthropometric measurements of 58 dimensions were carried out on 286 male and 210 female college students. The measurement results were presented on descriptive statistics using mean, standard deviation, and percentile values. Dimension comparisons between sexes and ethnicities were also performed with the t-test and the Mann-Whitney test. The results of the study showed that significant differences were observed on almost all anthropometric dimensions, where the male participants had longer and wider dimensions than the females. The comparisons of male dimensions showed that significant differences were observed on the 13 dimensions, with the tendency of the Javanese participants to have more extended and wider leg dimensions. On the other
\end{abstract}


hand, the Bataknese tended to have higher values on the dimensions associated with the width, such as foot width and mouth width. The comparison of the female dimensions indicated that significant differences existed on 27 dimensions, with the tendency of the Bataknese to have wider and longer dimensions on a rear-facing sitting position, while the Javanese tend to have wider and longer hand dimensions.

Keywords: dimensions, anthropometry, comparison, Bataknese, Javanese

\section{PENDAHULUAN}

Salah satu indikator produk sukses adalah kenyamanan dan kemudahan dari produk tersebut. Kenyamanan produk dapat dicapai dengan berbagai hal, salah satunya dengan memperhatikan aspek kesesuaian dimensi produk dengan dimensi manusia sebagai pengguna dari produk tersebut. Ilmu yang mempelajari mengenai dimensi tubuh manusia dan aplikasinya pada rancangan suatu produk disebut dengan antropometri (Wickens dkk., 2004).

Antropometri manusia bervariasi tergantung berbagai faktor. Variasi antropometri dapat disebabkan oleh usia, jenis kelamin, ras dan suku bangsa, serta pekerjaan (Wickens, dkk., 2004). Berbagai penelitian telah dilakukan untuk membuktikan hal ini, baik pada usia, jenis kelamin, pekerjaan dan suku bangsa (Mehrparvar dkk, 2015; Wickens dkk., 2004). Beberapa penelitian di Asia Pasifik juga telah dilakukan untuk melihat pengaruh perbedaan ras dan suku bangsa terhadap perbedaan antropometri. Penelitian Chuan, dkk. (2010) membandingkan antropometri orang Indonesia dengan orang Singapura serta orang Indonesia keturunan China dengan orang Singapura keturunan China yang menunjukan Orang Singapura secara umum memiliki dimensi antropometri yang lebih besar daripada orang Indonesia. Penelitian Malla, dkk. (2012) membandingkan antropometri bayi di Nepal berdasarkan suku bangsa, yang menunjukkan terdapat perbedaan beberapa dimensi antropometri antara bayi dari keenam suku yang berbeda. Selain itu, Klamkay, dkk. (2008) juga meneliti perbedaan antropometri antara masyarakat Thailand Selatan dengan Thailand Tengah di mana didapatkan perbedaan pada beberapa dimensi antropometri.

Indonesia memiliki wilayah yang sangat luas dengan beranekaragam suku bangsa. Namun, penelitian yang membahas pengaruh perbedaan suku bangsa terhadap dimensi antropometri masih sangat terbatas. Penelitian antropometri yang membahas hal tersebut baru dilakukan pada mahasiswa bersuku suku Jawa, suku Sunda, dan Minangkabau (Widyanti, dkk., 2015). Di sisi lain, Indonesia memiliki lebih dari 300 suku bangsa. Suku dengan jumlah penduduk terbesar saat ini adalah suku Jawa, sedangkan suku Batak merupakan salah satu suku bangsa dengan tingkat migrasi tertinggi di Indonesia (Perwira, 2001). Penelitian ini dilakukan dalam rangka mengumpulkan data antropometri kedua suku bangsa tersebut, khususnya pada populasi mahasiswa. Menurut Heald, mahasiswa diambil sebagai objek penelitian karena ukuran tubuh mahasiswa cenderung sudah stabil dan sudah dalam tumbuh kembang maksimal karena kebanyakan mahasiswa berusia di atas 18 tahun (Artaria, 2009). Penelitian ini juga bertujuan untuk melihat karakteristik antropometri dari masing-masing suku dengan melakukan perbandingan dimensi antar suku sekaligus faktor terkait seperti jenis kelamin.

\section{METODE}

Penelitian ini adalah penelitian non eksperimen dan bersifat deskriptif. Subjek adalah mahasiswa perguruan tinggi di Yogyakarta, yang terdiri atas 101 suku Batak dan 395 suku Jawa dan dipilih dengan convenience sampling. Kriteria inklusi adalah mahasiswa sarjana yang memiliki kedua orang tua bersuku Batak atau Jawa. Kriteria eksklusi adalah mahasiswa 
yang memiliki cedera maupun kecatatan. Populasi target adalah mahasiswa Indonesia bersuku Jawa dan Batak, sedangkan populasi terjangkau merupakan mahasiswa sarjana perguruan tinggi di Yogyakarta yang bersuku Jawa dan Batak. Jumlah peserta penelitian dihitung berdasarkan International Organization for Standardization (ISO) General Requirements for Establishing Anthropometric Databases (ISO 15535:2003). Standar ini memperkirakan ukuran sampel yang dibutuhkan dengan memperhatikan variasi dari dimensi yang diukur dengan koefisien variasi $(\mathrm{CV})$, tingkat akurasi yang diinginkan $(\alpha)$ serta tingkat keyakinan (Hu, dkk., 2007). Dalam penelitian ini, CV ditentukan sebesar 20 dan tingkat akurasi yang diinginkan sebesar 10\%, sehingga jumlah sampel yang dibutuhkan sebesar 37 orang. Dengan demikian jumlah subjek penelitian sudah melebihi dari jumlah yang disyaratkan. Pengukuran dilakukan pada 58 dimensi antropometri (Tabel 1) dengan menggunakan kursi antropometri, jangka sorong, meter tape dengan akurasi $0,1 \mathrm{~mm}$, dan penimbang berat badan dengan akurasi 0,1 gram. Alat ukur yang digunakan telah dikalibrasi sesuai dengan aturan dan standar yang berlaku. Definisi dari dimensi antropometri yang digunakan pada penelitian ini mengacu pada beberapa referensi seperti Stevenson (1989), Nurmianto (1991) dan Pheasant (2006). Pengukuran dilakukan di pagi hingga sore hari oleh beberapa mahasiswa terlatih. Peserta diminta menanggalkan alas kaki selama proses pengukuran dilakukan.

Tabel 1

Dimensi antropometri dan singkatan

\begin{tabular}{|c|c|c|c|c|c|}
\hline No. & Dimensi & Singkatan & No. & Dimensi & Singkatan \\
\hline \multicolumn{3}{|c|}{$\begin{array}{c}\text { Dimensi Antropometri Posisi Duduk } \\
\text { Menghadap Samping }\end{array}$} & \multicolumn{3}{|c|}{ Dimensi Antropometri Posisi Berdiri } \\
\hline 1. & Tinggi duduk tegak & tdt & 1. & Tinggi badan tegak & tbt \\
\hline 2. & $\begin{array}{l}\text { Tinggi duduk } \\
\text { normal }\end{array}$ & $\operatorname{tdn}$ & 2. & Tinggi mata berdiri & tmb \\
\hline 3. & Tinggi mata duduk & tmd & 3. & Tinggi bahu berdiri & tbb \\
\hline 4. & Tinggi bahu duduk & tbd & 4. & Tinggi siku berdiri & tsb \\
\hline 5. & Tinggi siku duduk & tsd & 5. & $\begin{array}{l}\text { Tinggi pinggang } \\
\text { berdiri }\end{array}$ & tpb \\
\hline 6. & $\begin{array}{l}\text { Tinggi sandaran } \\
\text { punggung }\end{array}$ & tsp & 6. & $\begin{array}{l}\text { Jangkauan tangan } \\
\text { ke atas }\end{array}$ & jta \\
\hline 7. & Tinggi pinggang & tp & 7. & $\begin{array}{l}\text { Panjang lengan } \\
\text { bawah sampai } \\
\text { ujung }\end{array}$ & plbujung \\
\hline 8. & Tebal perut duduk & tpr & 8. & $\begin{array}{l}\text { Panjang lengan } \\
\text { bawah }\end{array}$ & plb \\
\hline 9. & Tebal paha & tph & 9. & Tinggi lutut berdiri & $\mathrm{tlb}$ \\
\hline 10. & Tinggi popliteal & tpl & 10. & Tebal perut & tp \\
\hline 11. & Pantat popliteal & $\mathrm{pp}$ & 11. & Berat Badan & $\mathrm{bb}$ \\
\hline 12. & Pantat ke lutut & $\mathrm{pl}$ & 12. & $\begin{array}{l}\text { Jangkauan tangan } \\
\text { ke depan }\end{array}$ & jtd \\
\hline \multirow{2}{*}{\multicolumn{3}{|c|}{$\begin{array}{c}\text { Dimensi Antropometri Posisi Duduk } \\
\text { Menghadap Belakang }\end{array}$}} & 13. & Rentang tangan & $\mathrm{rt}$ \\
\hline & & & \multicolumn{3}{|c|}{ Dimensi Antropometri Kaki } \\
\hline 1. & Lebar pinggul & $\operatorname{lp}$ & 1. & $\begin{array}{l}\text { Panjang telapak } \\
\text { kaki }\end{array}$ & ptk \\
\hline 2. & Lebar pinggang & $\operatorname{lpg}$ & 2. & $\begin{array}{l}\text { Panjang telapak } \\
\text { lengan kaki/ Tumit } \\
\text { ke Pangkal }\end{array}$ & tkp \\
\hline 3. & Siku ke siku & ss & 3. & $\begin{array}{l}\text { Panjang kaki } \\
\text { sampai jari } \\
\text { kelingking/ Tumit } \\
\text { ke Jari Kelingking }\end{array}$ & tkjk \\
\hline & Dimensi Antropom & epala & 4. & Lebar kaki & $\mathrm{lk}$ \\
\hline
\end{tabular}




\begin{tabular}{clc}
\hline No. & \multicolumn{1}{c}{ Dimensi } & Singkatan \\
\hline 1. & Panjang kepala & pk \\
\hline 2. & Lebar kepala & lkep \\
\hline 3. & $\begin{array}{l}\text { Diameter maksimum } \\
\text { dari dagu }\end{array}$ & dmd
\end{tabular}

$\begin{array}{ll}\text { 4. Dagu ke puncak } & \text { dpk } \\ \text { kepala }\end{array}$

\begin{tabular}{rlc}
\hline 5. & $\begin{array}{l}\text { Telinga ke puncak } \\
\text { kepala }\end{array}$ & tpk \\
\hline 6. & $\begin{array}{l}\text { Telinga ke belakang } \\
\text { kepala }\end{array}$ & tbk \\
\hline 7. & Antara dua telinga & adt \\
\hline 8. & $\begin{array}{l}\text { Mata ke belakang } \\
\text { kepala }\end{array}$ & $\mathrm{mbk}$ \\
\hline 9. & $\begin{array}{l}\text { Mata ke puncak } \\
\text { kepala }\end{array}$ & $\mathrm{mpk}$ \\
\hline 10. & $\begin{array}{l}\text { Antara dua pupil } \\
\text { mata }\end{array}$ & $\mathrm{adp}$ \\
\hline 11. & $\begin{array}{l}\text { Hidung ke puncak } \\
\text { kepala }\end{array}$ & $\mathrm{hpk}$ \\
\hline 12. & $\begin{array}{l}\text { Hidung ke belakang } \\
\text { kepala }\end{array}$ & $\mathrm{hbk}$ \\
\hline 13. & $\begin{array}{l}\text { Mulut ke puncak } \\
\text { kepala }\end{array}$ & $\mathrm{mupk}$ \\
\hline 14. & Lebar mulut \\
\hline
\end{tabular}

\begin{tabular}{|c|c|c|}
\hline No. & Dimensi & Singkatan \\
\hline 5. & Lebar tangkai kaki & ltk \\
\hline 6. & Tinggi mata kaki & lmk \\
\hline 7. & $\begin{array}{l}\text { Tinggi bagian } \\
\text { tengah telapak } \\
\text { kaki/ Tinggi } \\
\text { tempurung telapak } \\
\text { kaki }\end{array}$ & lttk \\
\hline 8. & $\begin{array}{l}\text { Jarak horisontal } \\
\text { tangkai mata kaki/ } \\
\text { Tumit ke Mata } \\
\text { Kaki }\end{array}$ & tmk \\
\hline \multicolumn{3}{|c|}{ Dimensi Antropometri Tangan } \\
\hline \multirow[t]{5}{*}{1.} & 1-1. Panjang jari 1 & pj1 \\
\hline & 1-2. Panjang jari 2 & pj2 \\
\hline & 1-3. Panjang jari 3 & $\mathrm{pj} 3$ \\
\hline & 1-4. Panjang jari 4 & $\mathrm{pj} 4$ \\
\hline & 1-5. Panjang jari 5 & pj5 \\
\hline 2. & $\begin{array}{l}\text { Pangkal ke ruas } \\
\text { tangan }\end{array}$ & $\mathrm{pkr}$ \\
\hline 3. & Lebar jari $2,3,4,5$ & $\mathrm{lj}$ \\
\hline 4. & $\begin{array}{l}\text { Lebar telapak } \\
\text { tangan }\end{array}$ & ltt \\
\hline 5. & $\begin{array}{l}\text { Panjang telapak } \\
\text { tangan }\end{array}$ & $\mathrm{ptt}$ \\
\hline
\end{tabular}

Data disajikan dengan menggunakan statistika deskriptif dalam rerata, simpang baku, dan nilai-nilai persentil. Selanjutnya, uji asumsi seperti uji kenormalan dilakukan untuk menentukan metode statistik yang tepat untuk perbandingan rerata. Perbandingan rerata dilakukan antar jenis kelamin dan suku untuk setiap dimensi. Perbandingan rerata dilakukan dengan uji t tidak berpasangan untuk data parametrik, dan uji Mann-Whitney untuk data nonparametrik. Selanjutnya, untuk mengilustrasikan perbandingan dimensi, dibuat stick figure dengan nilai rerata untuk masing-masing suku dan jenis kelamin. Proses pengolahan data dilakukan dengan software minitab, Ms. Excel, dan SPSS.

\section{HASIL DAN PEMBAHASAN}

Dari seluruh subjek yang diperiksa, diperoleh data berat badan, tinggi badan, dan usia dalam rerata, simpang baku, dan rentang seperti ditunjukkan pada Tabel 2 dan 3 .

Tabel 2

Berat badan, tinggi, dan usia subjek bersuku Batak $(n=101)$

\begin{tabular}{lcccc}
\hline \multirow{2}{*}{ Dimensi } & \multicolumn{2}{c}{ Laki-laki $(\mathrm{n}=51)$} & \multicolumn{2}{c}{ Perempuan $(\mathrm{n}=50)$} \\
\cline { 2 - 5 } & Rerata \pm SB & Rentang & Rerata \pm SB & Rentang \\
\hline Berat badan $(\mathrm{kg})$ & $66.60 \pm 11.24$ & $46-95$ & $53.71 \pm 8.18$ & $42-76,5$ \\
Tinggi $(\mathrm{cm})$ & $170.08 \pm 6.51$ & $156-185.5$ & $156.58 \pm 5.64$ & $147-171$ \\
Usia (tahun) & $20.64 \pm 1.89$ & $17-26$ & $19.72 \pm 1.47$ & $17-23$ \\
\hline
\end{tabular}


Tabel 3

Berat badan, tinggi, dan usia subjek bersuku Jawa $(\mathrm{n}=395)$

\begin{tabular}{lcccc}
\hline \multirow{2}{*}{ Dimensi } & \multicolumn{2}{c}{ Perempuan $(\mathrm{n}=160)$} & \multicolumn{2}{c}{ Laki-laki $(\mathrm{n}=235)$} \\
\cline { 2 - 5 } & Rerata \pm SB & Rentang & Rerata \pm SB & Rentang \\
\hline Berat badan $(\mathrm{kg})$ & $49.99 \pm 6.21$ & $37-67.5$ & $63.35 \pm 10.64$ & $41-92$ \\
Tinggi $(\mathrm{cm})$ & $157.20 \pm 4.69$ & $144-168.5$ & $170.76 \pm 5.50$ & $157-189$ \\
Usia (tahun) & $19.82 \pm 0.70$ & $18-21$ & $19.80 \pm 0.75$ & $17-22$ \\
\hline
\end{tabular}

Tabel 4 merupakan hasil pengukuran untuk setiap dimensi yang disajikan dalam nilainilai persentil. Selanjutnya, Tabel 5 menampilkan rerata, standar deviasi dan hasil perbandingan rerata antara peserta suku Jawa dan Batak dalam setiap jenis kelamin untuk setiap dimensi.

Tabel 4

Nilai persentil untuk semua dimensi berdasarkan suku dan jenis kelamin (satuan dalam $\mathrm{cm}$ )

\begin{tabular}{|c|c|c|c|c|c|c|c|c|c|c|c|c|}
\hline \multirow{3}{*}{ Dimensi } & \multicolumn{6}{|c|}{ Peserta laki-laki $(\mathrm{n}=286)$} & \multicolumn{6}{|c|}{ Peserta perempuan $(\mathrm{n}=210)$} \\
\hline & \multicolumn{3}{|c|}{ Batak $(n=51)$} & \multicolumn{3}{|c|}{ Jawa $(n=235)$} & \multicolumn{3}{|c|}{ Batak $(n=50)$} & \multicolumn{3}{|c|}{ Jawa $(n=160)$} \\
\hline & P5* & P50* & P95* & P5 & P50 & P95 & P5 & P50 & P95 & P5 & P50 & P95 \\
\hline tdt & 82.38 & 89 & 97 & 83 & 88.6 & 94.3 & 77.67 & 82.4 & 87.86 & 77.31 & 82.45 & 86.98 \\
\hline $\operatorname{tdn}$ & 79.6 & 86 & 92.6 & 80.93 & 86 & 92.58 & 75.81 & 80.3 & 84.97 & 75.4 & 80.5 & 85 \\
\hline tmd & 70.26 & 77 & 84.4 & 71 & 77 & 83 & 66.36 & 71.05 & 76.64 & 64 & 70.5 & 75.98 \\
\hline tbd & 55.5 & 60.2 & 67.9 & 54.43 & 59.1 & 64.18 & 49.98 & 55.2 & 60.18 & 50.21 & 55 & 60 \\
\hline tsd & 17.38 & 23.5 & 30.4 & 17.66 & 23 & 28.84 & 17.78 & 21.65 & 26.06 & 18 & 22.3 & 27.38 \\
\hline tsp & 43.65 & 48.4 & 55.69 & 42 & 50 & 57.47 & 42.21 & 46.9 & 52.49 & 38.53 & 46.05 & 51.69 \\
\hline tp & 17.25 & 22.4 & 27.5 & 17 & 22.5 & 27.85 & 20.5 & 23.8 & 28.7 & 19 & 23.6 & 27.48 \\
\hline tpr & 16.6 & 22 & 28.94 & 17.15 & 22 & 27.63 & 14.11 & 19 & 25.34 & 15.1 & 19.6 & 25 \\
\hline tph & 11.3 & 15 & 19.2 & 11.87 & 15 & 18 & 11.73 & 14.75 & 16.91 & 10.5 & 14 & 17.5 \\
\hline tpl & 36.2 & 43 & 48.96 & 39.03 & 42.75 & 46.3 & 37.72 & 41 & 43.84 & 37 & 40 & 44 \\
\hline $\mathrm{pp}$ & 40.25 & 46.6 & 51.2 & 42.57 & 47.9 & 52.53 & 39.72 & 44.2 & 50.2 & 40.4 & 45 & 49.91 \\
\hline $\mathrm{pl}$ & 50.6 & 58 & 65.5 & 54.5 & 59 & 65 & 50.78 & 55.75 & 62.7 & 51.3 & 55.6 & 60.7 \\
\hline lp & 26.62 & 34.5 & 43.24 & 27.26 & 33.05 & 41.07 & 29.51 & 39.8 & 47.16 & 27 & 32 & 39 \\
\hline $\operatorname{lpg}$ & 23.54 & 28.5 & 36.5 & 23.06 & 27.5 & 33.5 & 23.1 & 26 & 32.1 & 20.79 & 26 & 30 \\
\hline ss & 33.8 & 43 & 51.6 & 34.44 & 42.5 & 52 & 34.56 & 41.35 & 50.58 & 30.51 & 38 & 45.95 \\
\hline tbt & 158.12 & 170 & 180.9 & 161.88 & 171 & 179.22 & 148 & 156 & 167.8 & 149 & 158 & 164 \\
\hline tmb & 145.4 & 158 & 169.86 & 149.7 & 159 & 168 & 136 & 144.35 & 155.78 & 137.04 & 146.15 & 153.98 \\
\hline tbb & 129.8 & 141.2 & 151.56 & 132 & 141 & 150.48 & 121.44 & 129 & 139.5 & 121.02 & 130 & 137.48 \\
\hline tsb & 98.6 & 106.5 & 117.32 & 100 & 106 & 113.36 & 90.5 & 97 & 104 & 92.98 & 98 & 104 \\
\hline $\mathrm{tpb}$ & 87.3 & 99 & 107.2 & 92 & 100 & 110.65 & 87.9 & 95 & 103.65 & 88 & 96 & 103 \\
\hline jta & 196.4 & 219 & 231.64 & 202.73 & 218 & 231 & 184.38 & 197 & 210.9 & 185.86 & 199.5 & 209.9 \\
\hline plbujung & 37.9 & 45 & 49.32 & 41.6 & 45 & 49 & 35.45 & 39.1 & 44.78 & 37.26 & 41.45 & 45.08 \\
\hline plb & 21.5 & 26 & 29.45 & 22.96 & 26 & 29.25 & 19.2 & 22.5 & 27.78 & 20.76 & 24.25 & 28 \\
\hline tlb & 42.8 & 48 & 52 & 43 & 48 & 52.9 & 39.3 & 43 & 48.28 & 40 & 43.6 & 48 \\
\hline tp & 14.55 & 21 & 26.15 & 15.16 & 20.8 & 26 & 15.55 & 21 & 27.09 & 13.52 & 19 & 24.48 \\
\hline $\mathrm{bb}$ & 48.6 & 67 & 91.48 & 48 & 62.7 & 82 & 42.73 & 51.75 & 73.28 & 40.64 & 50 & 61.3 \\
\hline jtd & 68.18 & 82 & 91.94 & 74.95 & 82.1 & 90.33 & 66.55 & 75.25 & 82.54 & 68 & 75.5 & 82 \\
\hline $\mathrm{rt}$ & 161 & 173 & 187.2 & 164 & 175 & 187.15 & 146.28 & 155.55 & 168.12 & 147.5 & 158.95 & 168 \\
\hline pj1 & 5.24 & 6.33 & 7.5 & 5.5 & 6.73 & 7.5 & 5.1 & 6 & 6.55 & 5.01 & 6 & 6.9 \\
\hline pj2 & 6.67 & 7.4 & 8.73 & 6.9 & 7.5 & 8.6 & 6.08 & 6.8 & 7.42 & 6.3 & 7 & 7.9 \\
\hline pj3 & 7.47 & 8 & 9.25 & 7.5 & 8.4 & 9.5 & 6.74 & 7.5 & 8.06 & 7 & 7.7 & 8.5 \\
\hline pj4 & 6.77 & 7.53 & 8.82 & 7 & 7.7 & 8.5 & 6.15 & 7 & 7.9 & 6.3 & 7 & 7.71 \\
\hline pj5 & 5.17 & 6.1 & 7 & 5.46 & 6.2 & 7 & 4.95 & 5.5 & 6.35 & 5 & 5.5 & 6.4 \\
\hline $\mathrm{pkr}$ & 9.69 & 10.5 & 12 & 9.8 & 11 & 12 & 8.45 & 9.2 & 10.35 & 8.8 & 10 & 10.5 \\
\hline $\mathrm{lj}$ & 6.48 & 7.89 & 9 & 7 & 8 & 9 & 6.5 & 7.1 & 8.05 & 6 & 7 & 8 \\
\hline litt & 8.5 & 10.2 & 11.62 & 9.1 & 10.3 & 11.5 & 8.24 & 9.1 & 10 & 8.18 & 9 & 10 \\
\hline $\mathrm{ptt}$ & 16.9 & 19 & 20.65 & 17.45 & 19 & 21 & 15.2 & 16.7 & 18.95 & 15.9 & 17.2 & 18.5 \\
\hline ptk & 22.64 & 25 & 27.58 & 23.33 & 25.5 & 27.5 & 21.06 & 22.55 & 25.18 & 21 & 23 & 25 \\
\hline tkp & 17.85 & 20.5 & 22.5 & 18.25 & 20.3 & 22.5 & 17.3 & 18.5 & 20.5 & 16.49 & 18.4 & 20 \\
\hline tkjk & 19 & 21 & 23.08 & 19.5 & 21 & 23 & 17.53 & 19 & 21.09 & 17.22 & 19 & 20.5 \\
\hline $1 \mathrm{k}$ & 9 & 10.11 & 12 & 8.5 & 10 & 11.4 & 7.78 & 9.5 & 10.84 & 8 & 9 & 10 \\
\hline ltk & 4.25 & 6.2 & 7.75 & 5 & 6 & 7.34 & 4 & 4.55 & 5.5 & 4.43 & 5.5 & 6.5 \\
\hline lmk & 6 & 7.9 & 10.5 & 5.88 & 7.5 & 9.5 & 5.7 & 6.9 & 7.68 & 5 & 6.5 & 8 \\
\hline lttk & 5.56 & 7.5 & 10 & 5.76 & 7.2 & 9 & 5.75 & 7.1 & 8.2 & 5 & 6.5 & 8 \\
\hline tmk & 2.1 & 4.3 & 6.15 & 2.5 & 4.5 & 6.74 & 2.35 & 3.5 & 5.15 & 2.5 & 4 & 5.5 \\
\hline pk & 16.82 & 19.45 & 21.73 & 17 & 19.1 & 21.5 & 15.16 & 17 & 19.06 & 15.5 & 18 & 21 \\
\hline $\mathrm{lk}$ & 13.8 & 16.3 & 19.44 & 14 & 16.5 & 19.84 & 13.11 & 14.9 & 16.26 & 13 & 15.5 & 18.98 \\
\hline
\end{tabular}




\begin{tabular}{|c|c|c|c|c|c|c|c|c|c|c|c|c|}
\hline \multirow{3}{*}{ Dimensi } & \multicolumn{6}{|c|}{ Peserta laki-laki $(n=286)$} & \multicolumn{6}{|c|}{ Peserta perempuan $(n=210)$} \\
\hline & \multicolumn{3}{|c|}{ Batak $(n=51)$} & \multicolumn{3}{|c|}{ Jawa $(n=235)$} & \multicolumn{3}{|c|}{ Batak $(n=50)$} & \multicolumn{3}{|c|}{ Jawa $(n=160)$} \\
\hline & P5* & P50* & P95* & $\overline{\mathrm{P} 5}$ & P50 & $\mathrm{P} 95$ & P5 & P50 & P95 & P5 & P50 & $\mathrm{P} 95$ \\
\hline $\mathrm{dpk}$ & 19 & 23.45 & 26.95 & 20.45 & 23 & 25.53 & 16.5 & 19.5 & 23.42 & 18.81 & 21.25 & 23.99 \\
\hline tpk & 11.18 & 14.5 & 17. 32 & 12 & 14.2 & 16.5 & 12.44 & 13.65 & 14.93 & 11.5 & 13.5 & 15.5 \\
\hline tbk & 6 & 9 & 11.75 & 6.34 & 9 & 11.68 & 6 & 7.5 & 10 & 6 & 9 & 12 \\
\hline adt & 13.8 & 17 & 20.08 & 13.58 & 17.4 & 21 & 14 & 16 & 17.8 & 12.91 & 15.2 & 18 \\
\hline mbk & 14 & 16.5 & 18.88 & 14.2 & 17 & 19.78 & 13.78 & 15.2 & 17.5 & 13.5 & 16.5 & 18.5 \\
\hline $\mathrm{mpk}$ & 9.4 & 12.3 & 15 & 9.5 & 12 & 14.84 & 9.7 & 11 & 12.45 & 9 & 11 & 13.03 \\
\hline adp & 5.8 & 7 & 8 & 5.97 & 7 & 8 & 6 & 6.5 & 7.34 & 5.5 & 6.5 & 7.5 \\
\hline hpk & 13.6 & 15.9 & 18.7 & 13 & 16 & 19 & 12 & 14 & 16.09 & 11.51 & 14.05 & 16.99 \\
\hline hbk & 18.64 & 20.5 & 22.5 & 18 & 20.5 & 23 & 17 & 19.35 & 21.73 & 16 & 19 & 22.5 \\
\hline mupk & 15.6 & 19 & 22.2 & 16 & 18.7 & 21.16 & 15.42 & 17.5 & 19.45 & 14.27 & 17.35 & 20.5 \\
\hline $\mathrm{lm}$ & 5 & 6 & 7.04 & 4.6 & 5.7 & 7 & 4.2 & 5 & 5.8 & 4.4 & 5.3 & 6 \\
\hline
\end{tabular}

Dari pengujian yang telah dilakukan dengan uji t tidak berpasangan maupun dengan uji Mann-Whitney yang hasilnya ditampilkan pada Tabel 5, perbedaan signifikan antara peserta laki-laki dan perempuan untuk masing-masing suku ditemukan pada hampir semua dimensi. Pada perbandingan antara peserta laki-laki dan perempuan bersuku Jawa didapatkan hanya satu dimensi yang perbedaannya tidak signifikan yaitu telinga ke belakang kepala (tbk) dengan $p$-value sebesar 0.531. Secara umum, peserta laki-laki bersuku Jawa memiliki hasil pengukuran yang lebih besar dalam semua dimensi kecuali tinggi pinggang duduk (tp) dibandingkan peserta perempuan bersuku Jawa. Pada perbandingan antara peserta laki-laki dan perempuan bersuku Batak, perbedaan yang signifikan ditemukan pada 54 dimensi. Perbedaan tidak signifikan ditemukan di empat dimesi yaitu tebal perut berdiri (tp), telinga ke puncak kepala (tpk), tebal paha duduk (tph), dan siku ke siku (ss) dengan nilai p sebesar 0.789, 0.506, 0.193, dan 0.122. Secara umum, dimensi laki-laki suku Batak lebih besar daripada perempuan. Namun demikian, terdapat dua dimensi dimana peserta perempuan bersuku Batak memiliki nilai yang lebih besar. Dimensi tersebut adalah tinggi pinggang duduk (tp) serta lebar pinggul (lp). Pada peserta dari kedua suku, dimensi tinggi pinggang duduk (tp) perempuan lebih besar daripada laki-laki, hal ini dapat disebabkan karena ukuran pinggul perempuan lebih besar daripada laki-laki. Perbedaan dimensi antropometri sebagai pengaruh jenis kelamin pada penelitian ini sejalan dengan beberapa penelitian sebelumnya seperti penelitian Lee, dkk. (2017) yang meneliti mengenai pengukuran antropometri berdasarkan jenis kelamin pada populasi di Singapura.

Berdasarkan perbandingan antara peserta laki-laki bersuku Batak dan Jawa ditemukan perbedaan yang signifikan pada 13 dimensi. Perbedaan signifikan dengan selisih terbesar ditemukan di tinggi pinggang berdiri (tpb) dan tinggi bahu duduk (tbd) dengan $\mathrm{p}=0.008$ untuk masing-masing dimensi. Peserta laki-laki bersuku Jawa cenderung memiliki dimensi kaki seperti panjang jari tangan, pantat ke lutut, pantat popliteal, dan tinggi pinggang pada saat berdiri yang lebih besar dibandingkan peserta laki-laki bersuku Batak. Pada dimensi panjang jari tangan, hampir pada semua jari tangan peserta bersuku Jawa dimensinya lebih besar signifikan daripada peserta bersuku Batak. Hasil yang sama juga ditemukan oleh penelitian dari Nidiaputri dan Ardiyanto (2017), dimana dalam penelitian tersebut didapatkan perbedaan yang signifikan pada 7 dimensi antropometri tangan antara peserta bersuku Jawa dan Batak. Pada peserta laki-laki bersuku Batak, dimensi yang lebih besar ditemukan pada dimensi terkait dengan lebar seperti lebar mulut dan lebar kaki serta dimensi pada posisi duduk (tinggi bahu duduk).

Tidak seperti pada peserta laki-laki, pada peserta perempuan bersuku Jawa dan Batak, perbedaan yang signifikan ditemukan pada 27 dimensi. Peserta perempuan bersuku Batak secara umum memiliki dimensi yang lebih besar pada posisi duduk menghadap belakang lebar pinggul (lp), lebar pinggang (lpg), dan siku ke siku (ss) dengan nilai p sebesar $<0.001$, 0.030 , dan $<0.001$. Pada dimensi tangan, umumnya peserta bersuku Jawa memiliki dimensi yang lebih besar daripada peserta bersuku Batak. Hal ini dapat dilihat pada bagian jari 
tangan, panjang tangan, panjang lengan maupun saat tangan posisi berdiri tegak. Pada bagian kepala, peserta perempuan bersuku Jawa mayoritas memiliki nilai yang lebih besar daripada perempuan suku Jawa. Pada dimensi kaki, peserta perempuan bersuku Jawa dan Batak ditemukan perbedaan yang signifikan pada lebar kaki (lk) dan lebar tangkai kaki (ltk) dengan nilai p sebesar 0.002 dan $<0.001$. Selain itu, perbedaan yang signifikan juga ditemukan pada tumit ke mata kaki (tmk) dan tinggi tempurung telapak kaki (lttk) dengan nilai p sebesar 0.002 dan <0.001. Pada perempuan suku Batak lebar tumit ke mata kaki (tmk) jaraknya lebih pendek daripada perempuan suku Jawa. Perbedaan yang signifikan pada tinggi tempurung telapak kaki (lttk), tumit ke mata kaki (tmk), maupun tinggi mata kaki (lmk) pada peserta bersuku Jawa dan Batak ini dapat disebabkan karena perbedaan budaya duduk yang berbeda pada suku Batak dan Jawa. Pada suku Batak ada kebiasaan duduk dengan melipat kaki bagian bawah sehingga ada kecenderungan tinggi mata kaki (lmk) dan jarak tempurung kaki dengan telapak kaki (lttk) lebih besar daripada suku Jawa.

Hasil penelitian ini menunjukkan perbedaan yang signifikan secara statistik pada beberapa dimensi antropometri antara peserta bersuku Batak dan Jawa $(p<0.05)$. Hasil penelitian ini sejalan dengan beberapa penelitian antropometri di Indonesia sebelumnya seperti Widyanti dkk. (2015) yang menemukan perbedaan signifikan pada beberapa suku bangsa di Indonesia seperti Jawa, Sunda, dan Minangkabau. Selain itu, hasil serupa juga ditemukan pada penelitian antropometri di negara lain seperti Iran. Mehrparvar, dkk. (2015) menemukan bahwa perbedaan signifikan ditemukan pada 19 dimensi antropometri pada subjek siswa sekolah yang berasal dari enam suku yang berbeda di Iran: Fars, Kurd, Lor, Baluch, Turk, dan Arab.

Tabel 5

Analisis dimensi antropometri berdasarkan suku Jawa dan Batak (satuan dalam $\mathrm{cm}$ )

\begin{tabular}{|c|c|c|c|c|c|c|c|c|c|c|c|c|}
\hline \multirow{3}{*}{ Dimensi } & \multicolumn{5}{|c|}{ Peserta laki-laki $(\mathrm{n}=286)$} & \multicolumn{5}{|c|}{ Peserta perempuan $(n=210)$} & \multirow[t]{3}{*}{ p-value ${ }^{3}$} & \multirow[t]{3}{*}{ p-value ${ }^{4}$} \\
\hline & \multicolumn{2}{|c|}{ Batak $(\mathrm{n}=51)$} & \multicolumn{2}{|c|}{ Jawa $(n=235)$} & \multirow{2}{*}{ p-value ${ }^{1}$} & \multicolumn{2}{|c|}{ Batak $(n=50)$} & \multicolumn{2}{|c|}{ Jawa $(n=160)$} & \multirow{2}{*}{ p-value ${ }^{2}$} & & \\
\hline & Rerata & SD & Rerata & SD & & Rerata & SD & Rerata & SD & & & \\
\hline tdt & 89.23 & 3.85 & 88.51 & 3.16 & $0.218^{\mathrm{A}}$ & 82.47 & 2.61 & 82.05 & 2.73 & $0.331^{\mathrm{A}}$ & $<0.001 * \mathrm{~A}$ & $0.789^{\mathrm{A}}$ \\
\hline $\operatorname{tdn}$ & 85.99 & 3.55 & 86.1 & 3.44 & $0.848^{\mathrm{A}}$ & 80.44 & 2.52 & 80.27 & 2.76 & $0.676^{\mathrm{A}}$ & $<0.001^{* \mathrm{~A}}$ & $<0.001 * \mathrm{~A}$ \\
\hline tmd & 76.79 & 3.77 & 77 & 3.41 & $0.716^{\mathrm{A}}$ & 71.34 & 2.79 & 70.39 & 3.22 & $0.046^{* \mathrm{~A}}$ & $<0.001^{* A}$ & $<0.001 * \mathrm{~A}$ \\
\hline tbd & 60.9 & 3.09 & 59.26 & 3.03 & $0.008 * \mathrm{~A}$ & 55.07 & 2.59 & 55.11 & 2.63 & $0.889^{\mathrm{A}}$ & $<0.001^{* A}$ & $<0.001 * \mathrm{~A}$ \\
\hline tsd & 23.93 & 3.05 & 23.06 & 3.2 & $0.072^{\mathrm{A}}$ & 21.57 & 2.19 & 22.29 & 2.67 & $0.057^{\mathrm{A}}$ & $<0.001 * \mathrm{~B}$ & $<0.001 * \mathrm{~A}$ \\
\hline tsp & 49.23 & 3.5 & 49.85 & 4.7 & $0.392^{\mathrm{A}}$ & 46.94 & 2.92 & 45.84 & 3.93 & $0.068^{\mathrm{A}}$ & $<0.001 * \mathrm{~B}$ & $<0.001 * \mathrm{~A}$ \\
\hline tp & 22.37 & 2.64 & 22.34 & 3.32 & $0.956^{\mathrm{A}}$ & 23.57 & 2.17 & 23.39 & 2.45 & $0.627^{\mathrm{A}}$ & $<0.001 * \mathrm{~B}$ & $<0.001 * \mathrm{~A}$ \\
\hline tpr & 22.43 & 3.54 & 22.09 & 2.99 & $0.525^{\mathrm{A}}$ & 19.43 & 2.82 & 19.85 & 2.83 & $0.367^{\mathrm{A}}$ & $<0.001 * \mathrm{~B}$ & $<0.001 * \mathrm{~A}$ \\
\hline tph & 15.09 & 2.55 & 14.88 & 1.92 & $0.506^{\mathrm{A}}$ & 14.53 & 1.61 & 13.93 & 2.13 & $0.036^{* A}$ & $<0.001 * \mathrm{~B}$ & $<0.001 * \mathrm{~A}$ \\
\hline tpl & 42.75 & 3.27 & 42.79 & 2.28 & $0.902^{\mathrm{A}}$ & 40.93 & 1.72 & 40.35 & 2.08 & $0.056^{\mathrm{A}}$ & $<0.001 *^{\mathrm{B}}$ & $<0.001 *^{\mathrm{A}}$ \\
\hline $\mathrm{pp}$ & 46.46 & 3.07 & 47.6 & 2.97 & $0.020^{* A}$ & 44.28 & 2.83 & 45.23 & 2.74 & $0.041^{* \mathrm{~A}}$ & $<0.001 *^{\mathrm{B}}$ & $<0.001 *^{\mathrm{A}}$ \\
\hline $\mathrm{pl}$ & 58.01 & 4.12 & 59.25 & 3.08 & $0.047^{* \mathrm{~A}}$ & 56.05 & 3.4 & 55.66 & 2.76 & $0.462^{\mathrm{A}}$ & $<0.001 *^{\mathrm{B}}$ & $<0.001 *^{\mathrm{A}}$ \\
\hline lp & 34.88 & 4.75 & 33.52 & 4.12 & $0.061^{\mathrm{A}}$ & 38.69 & 4.47 & 32.66 & 4.13 & $<0.001 * \mathrm{~A}$ & $<0.001^{* A}$ & $<0.001 *^{\mathrm{A}}$ \\
\hline lpg & 28.55 & 3.65 & 27.82 & 3.06 & $0.187^{\mathrm{A}}$ & 26.69 & 2.77 & 25.68 & 2.9 & $0.030^{* \mathrm{~A}}$ & $<0.001^{*^{\mathrm{A}}}$ & $<0.001 *^{\mathrm{A}}$ \\
\hline ss & 43.05 & 4.95 & 42.47 & 5.17 & $0.460^{\mathrm{A}}$ & 41.54 & 4.64 & 37.97 & 4.48 & $<0.001 * \mathrm{~A}$ & $<0.001 *^{\mathrm{B}}$ & $<0.001 *^{\mathrm{A}}$ \\
\hline tbt & 170.08 & 6.51 & 170.68 & 5.38 & $0.543^{\mathrm{A}}$ & 156.58 & 5.64 & 157.22 & 4.69 & $0.474^{\mathrm{A}}$ & $<0.001^{*^{\mathrm{A}}}$ & $<0.001 *^{\mathrm{A}}$ \\
\hline $\mathrm{tmb}$ & 158.48 & 6.95 & 159.03 & 5.37 & $0.530^{\mathrm{A}}$ & 144.95 & 5.7 & 145.54 & 5.21 & $0.520^{\mathrm{A}}$ & $<0.001 * \mathrm{~B}$ & $<0.001 * \mathrm{~A}$ \\
\hline tbb & 141.43 & 6.19 & 141.42 & 5.26 & $0.985^{\mathrm{A}}$ & 129.5 & 5.31 & 129.78 & 4.82 & $0.738^{\mathrm{A}}$ & $<0.001 * \mathrm{~B}$ & $<0.001 * \mathrm{~B}$ \\
\hline tsb & 106.75 & 5.2 & 106.35 & 4.04 & $0.542^{\mathrm{A}}$ & 96.95 & 3.96 & 98.38 & 3.78 & $0.029 * \mathrm{~A}$ & $<0.001 * \mathrm{~B}$ & $<0.001 * \mathrm{~A}$ \\
\hline tpb & 98.17 & 5.8 & 100.6 & 5.64 & $0.008^{* A}$ & 95.12 & 4.29 & 95.77 & 4.25 & $0.362^{\mathrm{A}}$ & $<0.001 * \mathrm{~B}$ & $<0.004 * \mathrm{~A}$ \\
\hline jta & 217.14 & 10.44 & 217.4 & 8.44 & $0.847^{\mathrm{A}}$ & 196.45 & 7.41 & 198.16 & 7.22 & $0.155^{\mathrm{A}}$ & $<0.001 * \mathrm{~B}$ & $<0.001 * \mathrm{~A}$ \\
\hline plbujung & 44.84 & 3.08 & 45.19 & 2.24 & $0.351^{\mathrm{A}}$ & 39.58 & 2.75 & 41.32 & 2.28 & $<0.001 * \mathrm{~A}$ & $<0.001 * \mathrm{~B}$ & $<0.001 * \mathrm{~A}$ \\
\hline plb & 26.01 & 2.23 & 26.13 & 1.91 & $0.723^{\mathrm{A}}$ & 22.81 & 2.3 & 24.09 & 2.11 & $<0.001 * \mathrm{~A}$ & $<0.001^{* \mathrm{~A}}$ & $<0.001 * \mathrm{~A}$ \\
\hline tlb & 47.64 & 2.79 & 48.02 & 2.91 & $0.384^{\mathrm{A}}$ & 43.3 & 2.23 & 43.6 & 2.71 & $0.439^{\mathrm{A}}$ & $<0.001^{* A}$ & $<0.001 * \mathrm{~A}$ \\
\hline tp & 21.08 & 3.28 & 20.92 & 3.41 & $0.757^{\mathrm{A}}$ & 20.91 & 2.97 & 18.8 & 3.07 & $<0.001 * \mathrm{~A}$ & $<0.001^{* \mathrm{~A}}$ & $0.55^{\mathrm{A}}$ \\
\hline $\mathrm{bb}$ & 66.6 & 11.23 & 63.35 & 10.64 & $0.063^{\mathrm{A}}$ & 53.71 & 8.18 & 49.99 & 6.21 & $<0.001 * \mathrm{~A}$ & $0.531^{\mathrm{A}}$ & $<0.001 * \mathrm{~A}$ \\
\hline jtd & 81.51 & 6.16 & 82.17 & 4.97 & $0.474^{\mathrm{A}}$ & 75.38 & 4.51 & 74.86 & 4.26 & $0.475^{\mathrm{A}}$ & $<0.001^{* \mathrm{~A}}$ & $0.003^{* \mathrm{~A}}$ \\
\hline $\mathrm{rt}$ & 173.84 & 7.72 & 175.28 & 7.19 & $0.235^{\mathrm{A}}$ & 156.19 & 7.13 & 158.56 & 6.2 & $0.038^{* A}$ & $<0.001^{* A}$ & $<0.001 * \mathrm{~A}$ \\
\hline PJ1 & 6.38 & 0.61 & 6.67 & 0.63 & $0.002 * \mathrm{~B}$ & 5.88 & 0.46 & 6.01 & 0.5 & $0.137^{\mathrm{A}}$ & $<0.001^{* \mathrm{~A}}$ & $<0.001 *^{\mathrm{A}}$ \\
\hline $\mathrm{PJ} 2$ & 7.43 & 0.55 & 7.64 & 0.53 & $0.005^{* \mathrm{~B}}$ & 6.75 & 0.37 & 6.97 & 0.44 & $0.002 *^{\mathrm{B}}$ & $<0.001 *^{\mathrm{B}}$ & $0.002 *^{\mathrm{B}}$ \\
\hline PJ3 & 8.17 & 0.52 & 8.43 & 0.57 & $0.002 * \mathrm{~B}$ & 7.44 & 0.41 & 7.7 & 0.49 & $0.002 *^{\mathrm{B}}$ & $<0.001 *^{\mathrm{A}}$ & $<0.001 *^{\mathrm{A}}$ \\
\hline PJ4 & 7.59 & 0.55 & 7.76 & 0.51 & $0.028 * \mathrm{~B}$ & 6.91 & 0.46 & 6.99 & 0.45 & $0.247^{\mathrm{B}}$ & $<0.001 *^{\mathrm{B}}$ & $<0.001 *^{\mathrm{A}}$ \\
\hline PJ5 & 6.13 & 0.47 & 6.26 & 0.5 & $0.201^{\mathrm{B}}$ & 5.59 & 0.4 & 5.6 & 0.41 & $0.826^{\mathrm{B}}$ & $<0.001 *^{\mathrm{B}}$ & $<0.001 *^{\mathrm{A}}$ \\
\hline $\mathrm{pkr}$ & 10.6 & 0.65 & 10.85 & 0.61 & $0.004 *^{\mathrm{B}}$ & 9.28 & 0.59 & 9.76 & 0.56 & $<0.001 *^{\mathrm{B}}$ & $<0.001 *^{\mathrm{B}}$ & $<0.001 *^{\mathrm{A}}$ \\
\hline
\end{tabular}




\begin{tabular}{|c|c|c|c|c|c|c|c|c|c|c|c|c|}
\hline \multirow{2}{*}{ Dimensi } & \multicolumn{5}{|c|}{ Peserta laki-laki $(\mathrm{n}=286)$} & \multicolumn{5}{|c|}{ Peserta perempuan $(n=210)$} & \multirow[t]{2}{*}{ p-value ${ }^{3}$} & \multirow[t]{2}{*}{ p-value ${ }^{4}$} \\
\hline & \multicolumn{2}{|c|}{ Batak $(n=51)$} & \multicolumn{2}{|c|}{ Jawa $(n=235)$} & \multirow{2}{*}{$\frac{p \text {-value }}{0.187^{B}}$} & \multicolumn{2}{|c|}{ Batak $(n=50)$} & \multicolumn{2}{|c|}{ Jawa $(n=160)$} & \multirow{2}{*}{$\frac{p \text {-value }{ }^{2}}{0.227^{B}}$} & & \\
\hline $\mathrm{lj}$ & 7.82 & 0.77 & 7.97 & 0.61 & & 7.22 & 0.44 & 7.08 & 0.56 & & $<0.001 *^{\mathrm{B}}$ & $<0.001 *^{\mathrm{A}}$ \\
\hline ltt & 10.12 & 0.87 & 10.3 & 0.66 & $0.258^{\mathrm{B}}$ & 9.14 & 0.53 & 9.05 & 0.58 & $0.217^{\mathrm{B}}$ & $<0.001 *^{\mathrm{B}}$ & $<0.001 * \mathrm{~A}$ \\
\hline $\mathrm{ptt}$ & 18.97 & 0.98 & 19.05 & 0.98 & $0.633^{\mathrm{A}}$ & 16.75 & 0.95 & 17.18 & 0.82 & $0.005^{* \mathrm{~A}}$ & $<0.001 *^{\mathrm{A}}$ & $<0.001 * \mathrm{~A}$ \\
\hline ptk & 25.26 & 1.48 & 25.41 & 1.25 & $0.519^{\mathrm{A}}$ & 22.92 & 1.15 & 22.95 & 1.07 & $0.866^{\mathrm{A}}$ & $<0.001 * \mathrm{~A}$ & $<0.001 * \mathrm{~A}$ \\
\hline tkp & 20.37 & 1.26 & 20.38 & 1.25 & $0.995^{\mathrm{A}}$ & 18.66 & 0.99 & 18.34 & 1.08 & $0.173^{\mathrm{B}}$ & $<0.001 * \mathrm{~B}$ & $<0.001 * \mathrm{~A}$ \\
\hline tkjk & 21.07 & 1.16 & 21.16 & 1.07 & $0.628^{\mathrm{A}}$ & 19.21 & 1.05 & 19.01 & 1.02 & $0.246^{\mathrm{A}}$ & $<0.001 * \mathrm{~A}$ & $<0.001 * \mathrm{~A}$ \\
\hline $\mathrm{lk}$ & 10.27 & 0.8 & 9.98 & 0.86 & $0.034 * \mathrm{~B}$ & 9.43 & 0.8 & 9.06 & 0.69 & $0.002 * \mathrm{~B}$ & $<0.001 * \mathrm{~B}$ & $<0.001 * \mathrm{~A}$ \\
\hline ltk & 6.1 & 0.89 & 6.1 & 0.68 & $0.694^{\mathrm{B}}$ & 4.61 & 0.47 & 5.41 & 0.63 & $<0.001 * \mathrm{~B}$ & $<0.001 * \mathrm{~B}$ & $<0.001 * \mathrm{~B}$ \\
\hline $\operatorname{lmk}$ & 7.97 & 1.29 & 7.53 & 1.16 & $0.027 * \mathrm{~A}$ & 6.79 & 0.61 & 6.6 & 0.92 & $0.143^{\mathrm{B}}$ & $<0.001 * \mathrm{~B}$ & $<0.001 * \mathrm{~A}$ \\
\hline lttk & 7.56 & 1.21 & 7.27 & 1 & $0.067^{\mathrm{B}}$ & 7.07 & 0.77 & 6.44 & 1 & $<0.001 * \mathrm{~B}$ & $<0.001 * \mathrm{~B}$ & $0.004 * \mathrm{~A}$ \\
\hline tmk & 4.37 & 1.18 & 4.55 & 1.26 & $0.428^{\mathrm{B}}$ & 3.54 & 0.75 & 3.95 & 0.97 & $0.002 * \mathrm{~A}$ & $<0.001 * \mathrm{~B}$ & $<0.001 * \mathrm{~A}$ \\
\hline pk & 19.39 & 1.34 & 19.15 & 1.41 & $0.250^{\mathrm{A}}$ & 16.85 & 1.01 & 18.2 & 1.56 & $<0.001 * \mathrm{~B}$ & $<0.001 * \mathrm{~B}$ & $<0.001 * \mathrm{~A}$ \\
\hline $\mathrm{lk}$ & 16.45 & 1.69 & 16.69 & 1.64 & $0.377^{\mathrm{A}}$ & 14.76 & 0.94 & 15.61 & 1.73 & $0.002 * \mathrm{~A}$ & $<0.001 * \mathrm{~A}$ & $<0.001 * \mathrm{~A}$ \\
\hline $\mathrm{dpk}$ & 23.37 & 2.17 & 22.94 & 1.54 & $0.092^{\mathrm{A}}$ & 19.74 & 1.83 & 21.29 & 1.52 & $<0.001 * \mathrm{~A}$ & $<0.001 *^{\mathrm{A}}$ & $<0.001 * \mathrm{~A}$ \\
\hline tpk & 14.24 & 1.71 & 14.26 & 1.38 & $0.925^{\mathrm{A}}$ & 13.73 & 0.69 & 13.54 & 1.2 & $0.321^{\mathrm{A}}$ & $<0.001 * \mathrm{~A}$ & $0.55^{\mathrm{A}}$ \\
\hline tbk & 9 & 1.73 & 9.06 & 1.54 & $0.835^{\mathrm{A}}$ & 7.7 & 1.03 & 8.96 & 1.7 & $<0.001 * \mathrm{~A}$ & $0.531^{\mathrm{A}}$ & $<0.001 * \mathrm{~A}$ \\
\hline adt & 16.98 & 1.98 & 17.3 & 2.23 & $0.315^{\mathrm{A}}$ & 15.99 & 1.09 & 15.4 & 1.56 & $0.016^{* \mathrm{~A}}$ & $<0.001 *^{\mathrm{A}}$ & $0.003 *^{\mathrm{A}}$ \\
\hline mbk & 16.53 & 1.38 & 16.99 & 1.56 & $0.040 * \mathrm{~A}$ & 15.45 & 1.11 & 16.41 & 1.56 & $<0.001 * \mathrm{~A}$ & $<0.001 *^{\mathrm{A}}$ & $<0.001 *^{A}$ \\
\hline mpk & 12.26 & 1.7 & 12 & 1.58 & $0.327^{\mathrm{A}}$ & 11.15 & 0.83 & 11.16 & 1.29 & $0.974^{\mathrm{A}}$ & $<0.001 *^{\mathrm{A}}$ & $<0.001 * \mathrm{~A}$ \\
\hline adp & 6.9 & 0.61 & 6.85 & 0.66 & $0.577^{\mathrm{B}}$ & 6.55 & 0.42 & 6.47 & 0.62 & $0.292^{\mathrm{B}}$ & $<0.001 *^{\mathrm{B}}$ & $0.002 *^{\mathrm{B}}$ \\
\hline hpk & 15.96 & 1.61 & 15.94 & 1.7 & $0.930^{\mathrm{A}}$ & 14.16 & 1.2 & 14.27 & 1.6 & $0.656^{\mathrm{A}}$ & $<0.001 *^{\mathrm{A}}$ & $<0.001 *^{\mathrm{A}}$ \\
\hline hbk & 20.57 & 1.2 & 20.5 & 1.5 & $0.771^{\mathrm{B}}$ & 19.42 & 1.29 & 19.29 & 1.79 & $0.641^{\mathrm{A}}$ & $<0.001 *^{\mathrm{B}}$ & $<0.001 * \mathrm{~A}$ \\
\hline mupk & 18.82 & 1.96 & 18.63 & 1.57 & $0.475^{\mathrm{A}}$ & 17.3 & 1.17 & 17.32 & 1.71 & $0.949^{\mathrm{B}}$ & $<0.001 *^{\mathrm{B}}$ & $<0.001 *^{\mathrm{A}}$ \\
\hline $\operatorname{lm}$ & 5.99 & 0.66 & 5.73 & 0.72 & $0.018^{*} \mathrm{~B}$ & 4.95 & 0.43 & 5.31 & 0.55 & $<0.001 *^{\mathrm{B}}$ & $<0.001 *^{\mathrm{B}}$ & $<0.001 *^{\mathrm{A}}$ \\
\hline
\end{tabular}

1) Laki-laki Jawa vs Batak, ${ }^{2}$ ) Perempuan Jawa vs Batak, ${ }^{3}$ ) Laki-laki vs Perempuan Jawa, ${ }^{4}$ ) Laki-laki vs Perempuan Batak

*) signifikan pada $p<0.05,{ }^{\mathrm{A}}$ ) perbandingan rerata dengan dengan uji t, ${ }^{\mathrm{B}}$ ) perbandingan rerata dengan uji Mann-Whitney

Perbedaan dimensi antropometri antara suku Batak dan Jawa yang ditemukan di penelitian ini dapat dipengaruhi oleh berbagai faktor. Kondisi geografi antara suku Batak dan suku Jawa dapat menjadi faktor yang berpengaruh pada perbedaan antropometri kedua suku. Suku Jawa yang terletak di Pulau Jawa bagian tengah dan timur berjauhan dengan suku Batak yang terletak di Provinsi Sumatra Utara, kedua daerah ini memiliki kondisi geografis yang berbeda. Hasil ini juga mendukung penelitian lain dari Widyanti, dkk. (2015) yang menemukan perbedaan antropometri antara suku Minangkabau di Pulau Sumatra dengan suku Jawa dan Sunda di Pulau Jawa. Selain itu, penelitian lain dari Sirajuddin, dkk. (1994) juga menemukan bahwa faktor geografis berpengaruh terhadap perbedaan genetis pada etnis di India bagian selatan.

Perbedaan adat dan budaya juga dapat menjadi faktor yang berpengaruh terhadap perbedaan antropometri antara kedua suku. Suku Batak sangat kental dengan adat dan budayanya hingga saat ini. Adat dan budaya ini dapat terlihat dalam kehidupan sehari-hari seperti kebiasaan posisi duduk maupun aktivitas yang lain. Hal ini sejalan dengan penelitian dari Iseri dan Arslan (2009) yang menjelaskan bahwa perbedaan kebiasaan, nutrisi, dan sosial ekonomi dapat mempengaruhi data antropometri.

Beberapa hasil penelitian sebelumnya seperti Mandahawi dkk. (2008) serta Nidiaputri dan Ardiyanto (2017) termasuk penelitian ini menunjukkan bahwa walaupun perbedaan signifikan dapat ditemukan pada beberapa dimensi antropometri, simpulan umum atas perbedaan dimensi yang ada masih sulit untuk ditarik. Untuk penelitian ini, hal tersebut dapat disebabkan karena beberapa hal seperti kesamaan ras antara suku Jawa dan suku Batak. Oleh karena itu, penelitian lanjutan dapat dilakukan dengan membandingkan antropometri suku bangsa di Indonesia dengan mempertimbangkan perbedaan ras.

Ilustrasi perbandingan antropometri dari nilai rerata pada peserta bersuku Jawa dan Batak untuk posisi berdiri dapat dilihat pada Gambar 1, sedangkan ilustrasi perbandingan antropometri untuk posisi duduk dapat dilihat pada Gambar 2. 


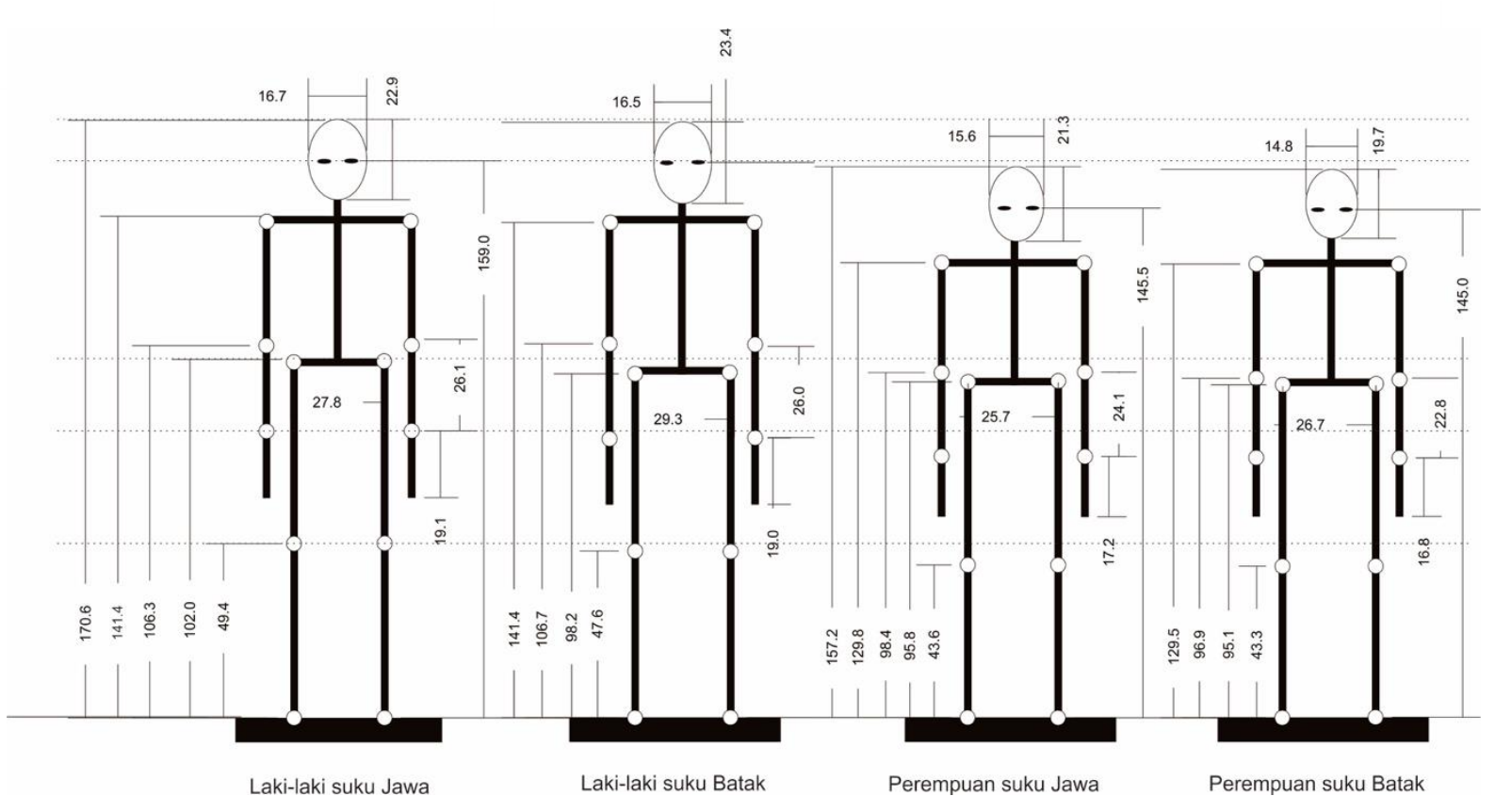

Gambar 1

Perbandingan dimensi antropometri peserta bersuku Jawa dan Batak pada posisi berdiri

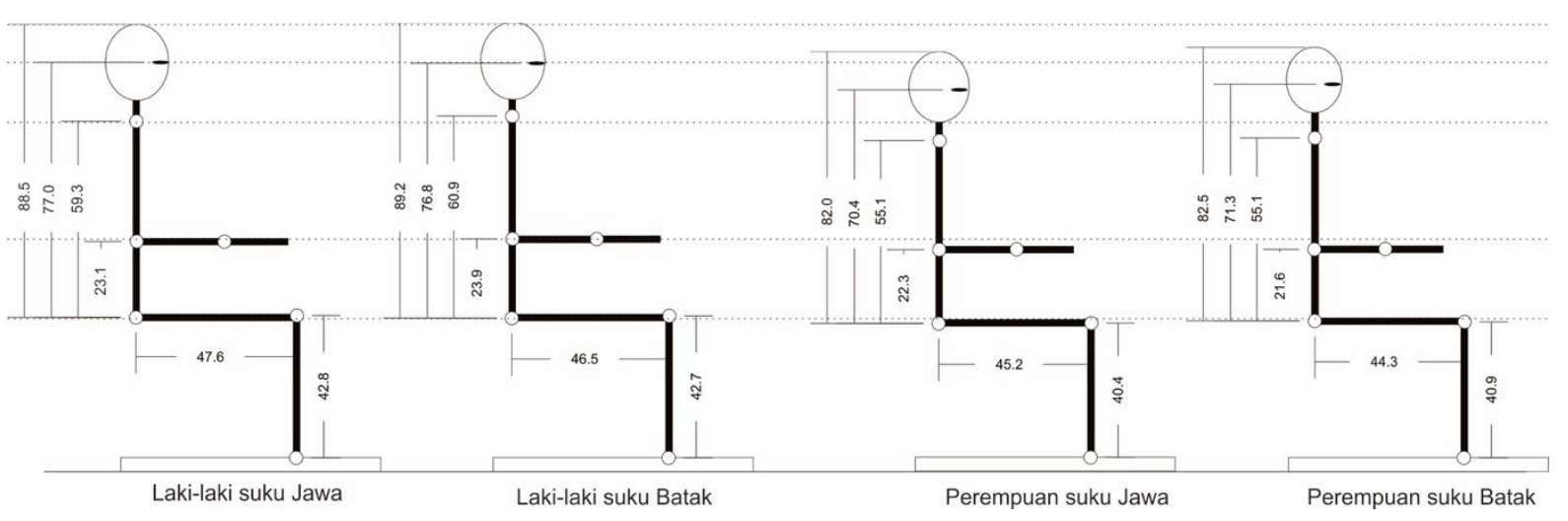

Gambar 2

Perbandingan dimensi antropometri peserta bersuku Jawa dan Batak pada posisi duduk

\section{SIMPULAN}

Penelitian ini menyajikan data antropometri baru mahasiswa Indonesia bersuku Batak dan Jawa. Hasil perbandingan menunjukkan bahwa secara umum peserta laki-laki baik pada peserta bersuku Jawa maupun Batak memiliki dimensi tubuh yang lebih besar daripada peserta perempuan. Selanjutnya, perbedaan yang signifikan ditemukan pada 13 dimensi dengan kecenderungan peserta laki-laki bersuku Jawa memiliki dimensi bagian kaki yang lebih besar daripada peserta laki-laki bersuku Batak $(\mathrm{p}<0.05)$. Di sisi lain, peserta bersuku Batak cenderung memiliki dimensi yang lebih besar pada dimensi terkait dengan lebar seperti lebar mulut dan lebar kaki dibandingkan peserta laki-laki bersuku Jawa. Pada peserta perempuan, perbedaan yang signifikan ditemukan pada 27 dimensi $(p<0.05)$. Peserta perempuan bersuku Batak secara umum memiliki dimensi yang lebih besar pada posisi duduk menghadap belakang, sedangkan peserta perempuan bersuku Jawa cenderung memiliki dimensi tangan yang lebih besar dibandingkan dengan peserta perempuan bersuku Batak. 


\section{DAFTAR PUSTAKA}

Artaria, M. D. 2009. Perbedaan antara Laki-laki dan Perempuan : Penelitian Antropometris pada Anak-anak Umur 6-19 Tahun. Jurnal Masyarakat Kebudayaan dan Politik, Vol. 22:343-349.

Chuan, T. K., Hartono, M., Kumar, N. 2010. Anthropometry of the Singaporean and Indonesian populations. International Journal of Industrial Ergonomics, Vol. 40:757-766.

Heald, F. P. 1969. Nutrition (Introduction) In FP Heald (ed) : Adolescent Nutrition and Growth. New York: Meredith Corporation

Hu, H., Li, Z., Yan, J., Wang, X., Xiao, H., Duan, J., Zheng, L. 2007. Anthropometric measurement of the Chinese elderly living in the Beijing area. International Journal of Industrial Ergonomics, Vol. 37:303 -311.

Iseri, A., Arslan, N. 2009. Estimated anthropometric measurements of Turkish adults and effects of age and geographical regions. Int. J. Ind. Ergon, Vol. 39:860-865.

Klamkay, J., Sungkhapong, A., Yodpijit, N., Patterson, P.E. 2008. Anthropometry of Southern Thai populations. International Journal of Industrial Ergonomics, Vol. 38:111-118.

Lee Y. C., Chen C. H., Khoo L. P. 2018. A Pilot Study of Gender Differences on Anthropometric Measurements in Singapore Population. AHFE 2017 Advances in Intelligent Systems and Computing, Vol 602. Springer, pp 42-51

Malla, K., Mall, T., Rao, S., Gauchan, E., Basnet, S., Koirala, D. P. 2012. Antropometric Measurements in Diff erent Ethnic groups of Nepalese New Borns, J Nepal Paediatr Soc, Vol. 32(1):1-8.

Mandahawi, N., Imrhan, S., Al-Shobaki, S., dan Sarder, B. 2008. Hand anthropometry survey for the Jordanian population. International Journal of Industrial Ergonomics, Vol. 38(11-12):966-976.

Mehrparvar, A. H., Mirmohammadi, S. J., Hafezi, R., Mostaghaci, M., dan Davari, M. H. 2015. Static anthropometric dimensions in a population of Iranian high school students: considering ethnic differences. Human factors, Vol. 57(3):447-460.

Nidiaputri, A. E., dan Ardiyanto, A. 2017. Hand Anthropometry of Indonesian Young Adult Females. Jurnal Ergonomi dan K3, Vol. 2(1):19-26.

Nurmianto, E. 1996. Ergonomi : Konsep Dasar dan Aplikasinya. Jakarta: PT Guna Widya.

Perwira, S. M. 2001. International and Internal Migration in Indonesia, Paper prepared for "AD Hoc Expert Group Meeting in the Theme "Migration and Development Opportunities and Challenges for Poverty Reduction in Escape Region"

Pheasant, S., Haslegrave, C. M. 2006. Body Space : Anthropometry, Ergonomics, and the Design of Work, $3^{\text {rd }}$ edition. Taylor dan Francis

Sirajuddin, S. M., Duggirala, R., Crawford, M. H. 1994. Population structure of the Chenchu and other south Indian tribal groups: relationships between genetic, anthropometric, dermatoglyphic, geographic, and linguistic distances. Hum. Biol.: Int. Rec. Res., Vol. 66:865-884.

Wickens, C. D., Lee, J. D., Liu, Y., Becker, S. E. G. 2004. An Introduction to Human Factors Engineering, $2^{\text {nd }}$ ed., New Jersey: Prentice Hall.

Widyanti, A., Susanti, L., Sutalaksana, I. Z., Muslim, K. 2015. Ethnic differences in Indonesian anthropomtery data : Evidence from three different largest ethnics, International Journal of Industrial Ergonomics, Vol. 47:72-78. 